Ernest Kwegyir-Afful was a neuroscience postdoc when he applied for a two-year fellowship at the FDA in the hope of getting to conduct research that would have an immediate impact. At the FDA's Center for Food Safety and Applied Nutrition in College Park, Maryland, Kwegyir-Afful worked on estimating the risk that small quantities of food allergens might endanger sensi-

"It's a field
that you would
enjoy if you
don't want
to think one-
dimensionally."
tive consumers. He came up with a computational method for risk analysis that was closely tailored to allergens. After finishing his fellowship last September, Kwegyir-Afful accepted a permanent position at the centre, doing similar work. Regulatory science is "a field that you would enjoy if you don't want to think one-dimensionally," he says, noting that he works with experts in topics such as toxicology or law. Communication skills and a team-oriented approach are essential, says Frances Richmond, director of the International Center for Regulatory Science at the University of Southern California in Los Angeles.

Regulatory-strategy units at pharmaceutical companies are good places to explore the regulatory side of industry, says Robert Meyer, who directed the FDA Office of Drug Evaluation before becoming vicepresident of global regulatory strategy for Merck at its campus in Upper Gwynedd, Pennsylvania. Company regulatory scientists would do well to understand the relevant laws for FDA reviewers, which can help company scientists to do the right experiments and to offer the FDA the data it needs to make decisions, says Meyer. That is especially true for people working at small companies, because they participate in many aspects of product development, says James Polli, co-principal investigator of an FDA CERSI at the University of Maryland in Baltimore.

Academic scientists, too, can address regulatory questions or advise the FDA. Subha Madhavan, a bioinformatician at Georgetown University, is building databases that will be used by FDA scientists looking to understand why people respond to drugs in different ways, and how vaccines might be linked to autoimmune disease. She regularly meets FDA staff to explore their needs, and expects to publish the work.

"Regulatory science is the field of the future, if you will, in terms of drug development and device development," says Wilhelm. "At some point, it will mean something to say, 'I am a regulatory scientist." -

Amber Dance is a freelance writer in Los Angeles, California.

\title{
TURNING POINT Adam de la Zerda
}

Adam de la Zerda was on track to become an electrical engineer when a personal loss prompted him to switch to cancer biology. Now a structural biologist at Stanford University in California, de la Zerda has developed a technique for imaging tumour cells.

\section{Why did you take up cancer biology?}

In my undergraduate programme at the Technion Israel Institute of Technology in Haifa, I focused on computer science, engineering and physics. When I started my $\mathrm{PhD}$ at Stanford, I was working on experimental quantum physics. But during winter break in my first year, a good friend passed away from cancer. That was a true turning point for me. I started examining how to apply my background to cancer research.

\section{Was it a difficult leap?}

No. Stanford has a flexible structure that can accommodate such transitions. I could have an adviser from anywhere in the university; I found an amazing one in Sanjiv Gambhir, who was working on molecular imaging. I knew that early detection of cancerous tissue could have prevented many cancer deaths, including my friend's. Gambhir agreed to let me join his lab without a biology background.

\section{How did you persuade him?}

I think my motivation convinced him, but I had also read a lot about his imaging work. I was able to explain why I was so excited about the prospects for direct applications. I launched a project to convert light into sound so we could look into tissue and find out whether cells are cancerous. My programming skills helped me to create our first real imaging unit using lasers and ultrasound systems.

\section{Why did you pursue a postdoc in chemistry?} As my $\mathrm{PhD}$ ended, I realized that much of what we do as biologists relies on chemistry. I had never taken a chemistry class, and wanted to study it. My dad has a PhD in chemistry, which also helped me to appreciate the subject. Luckily, Carolyn Bertozzi, a chemist at the University of California, Berkeley, accepted me as the first engineer in her lab. My knowledge of chemistry was at a first-year-undergraduate level, but I learned a lot, often from undergraduates.

\section{Did you plan to do a one-year postdoc?}

No - I had a three-year fellowship. Some people want to stay in their field and crank out papers; I wanted to expand my toolkit with organic chemistry. After a year, I saw an opportunity to apply for a faculty position in

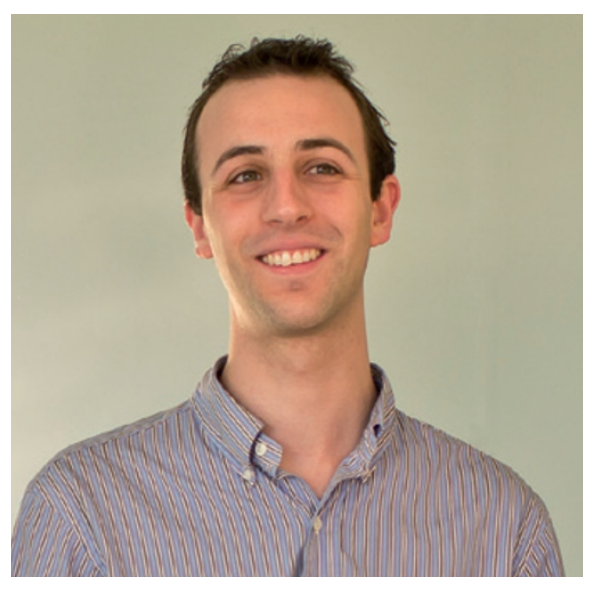

structural biology at Stanford. I was in no rush to leave the postdoc, but I felt ready. I got the position and started last autumn.

\section{How did you approach the interview?}

It is important to have an interesting story to tell when you apply. Given the tough job market, hiring committees are risk-averse. They don't want to hear, "I want to solve X problem." They want to hear, "This is exactly how I'm going to solve X problem." I feel fortunate that the search committee was willing to accept me, whereas others may have said I was at too early a stage.

\section{Last year, you won the Dale F. Frey Award for} Breakthrough Scientists. How will it help you? It is awarded by the Damon Runyon Cancer Research Foundation in New York, which contributes $100 \%$ of the donations it receives to research that will affect patients. Through the foundation, I have met venture capitalists whom I am trying to bring to research brainstorming sessions. I want to work out how best to translate my group's research and patents into commercial medical devices. I want the harsh feedback at the start of a project to help us to make sure that our technologies will help patients. We are willing to take big risks, but we want to make sure that there are big benefits.

\section{Should engineers explore life sciences?}

Yes. In the past year I have been teaching a class that exposes engineering students to biology; 300 students have taken it. I show them how engineering tools can solve problems in biology and medicine, especially in cancer and cardiovascular disease. Several engineering students have joined immunology and cardiology labs. That makes me extremely proud. 